\title{
Penggunaan Wiper Helm Otomatis Dan Kendali Kelistrikan Motor Berbasis Mikrkontroler Arduino
}

\author{
Samudra \\ Sistem Informasi STMIK Atma Luhur Pangkalpinang \\ Jl. Jend. Sudirman, Selindung, Pangkalpinang \\ Kepulauan Bangka Belitung \\ samusamudra@gmail.com
}

\author{
Dian Novianto \\ STMIK Atma Luhur \\ Jl. Jend. Sudirman, Selindung, Pangkalpinang \\ Kepulauan Bangka Belitung \\ diannovianto@atmaluhur.ac.id
}

\begin{abstract}
Abstrak-Pengendara sepeda motor dihadapkan dengan berbagai masalah saat berkendara seperti yang akan saya teliti berikut ini yaitu gangguan cuaca seperti air hujan yang mengenai kaca helm dan gangguan manusia seperti perampasan sepeda motor. Pada alat yang saya buat ini mempunyai dua fungsi yaitu fungsi wiper dan fungsi yang dapat mematikan sepeda motor dari jarak tertentu. Pada fungsi wiper helm digunakan sensor hujan sebagai alat yang mampu menditeksi curah air hujan dan motor servo sebagai penggerak wiper yang di proses oleh arduino Nano. Dan pada fungsi kendali listrik motor dari jarak tertentu terdapat tombol push button sebagai tombol emergency yang terletak pada helm dan di proses oleh arduino uno yang terkoneksi otomatis ke arduino Mega yang terletak pada motor melalui Bluetooth untuk mematikan sepeda motor. Sedangkan untuk menghidupkan motor disediakan keypad pada arduino Mega yang terletak pada motor yang digunakan sebagai tempat mengisi password untuk menghidupkan motor. Pada pengujian yang dilakukan, alat ini dapat mematikan sepeda motor dengan jarak 13 meter dan motor otomatis tidak dapat di hidupkan dan ketika ingin menghidupkan kembali motor tersebut harus dengan menekan mengisi password dengan cara menekan keypad yang berada pada sepeda motor.
\end{abstract}

Kata kunci-Mikrokontroler, Arduino Uno, Arduino Mega, Arduino Nano, Kelistrikan, Bluetooth, Relay

\section{PENDAHULUAN}

\section{A. Latar Belakang}

Menurut Badan Pusat Statistika perkembangan jumlah kendaaran sepeda motor di Indonesia sangat pesat. Pada tahun 2013 saja jumlah kendaraan sepeda motor di Indonesia sudah mencapai 84.732.652 unit dan di perkirakan setiap tahun akan terus bertambah. Pertumbuhan ini di sebabkan oleh banyak faktor yang mempengaruhinya antara lain, cendrungnya memilih kendaraan bermotor untuk berpergian dibandingkan menggunakan kendaraan umum. Hal ini cukup beralasan karena menggunakan kendaraan sepeda motor lebih cepat sampai tujuan ketimbang menggunakan kendaraan umum. Dengan pesatnya perkembangan sepeda motor dari tahun ke tahun di Indonesia muncul permasalahan yang di alami oleh pengguna sepeda motor dalam berkendara seperti hujan dan pembegalan.
Indonesia merupakan negara yang memiliki iklim tropis dengan tingkat curah hujan yang tinggi, hal ini yang menjadi momok bagi pengguna sepeda motor. Penggunaan helm pada saat hujan tentunya sangat mengganggu jarak pandang karena permukaan kaca depan terlalu banyak menerima air hujan, berbeda dengan kaca depan mobil yang memiliki wiper sebagai pembersih kaca saat hujan tiba.

Tak hanya itu pengendara sepeda motor pun di waswaskan dengan maraknya terjadi kasus pembegalan di jalanan. Pembegalan adalah sebuah aksi yang di lakukan dua atau sekelompok orang yang merampas sepeda motor di jalanan secara paksa.

Helm merupakan perlengkapan wajib dalam berkendara yang harus digunakan oleh pengendara sepeda motor karena termasuk dalam peraturan lalu lintas berkendara. peraturan ini terdapat pada undang-undang di Indonesia yang mengatur penggunaan helm seperti Pasal 106 ayat (8) UU No. 22/2009 yang berbunyi "Setiap orang yang mengemudikan Sepeda Motor dan Penumpang Sepeda Motor wajib mengenakan helm yang memenuhi standar nasional Indonesia." Helm juga dapat menjadi pelindung kepala agar terhindar dari benturan keras saat terjadi kecelakaan.

Berangkat dari pemikiran diatas, timbul sebuah gagasan untuk membuat sebuah helm yang dapat mengatasi masalah percikan air hujan yang dapat menganggu pandangan saat berkendara dan membantu pengendara ketika terjadi perampasan sepeda motor secara paksa di jalanan. Di harapkan alat atau perangkat ini dapat membantu pengguna sepeda motor dalam mengatasi berbagai masalah-masalah tersebut.

\section{B. Rumusan Masalah}

Sesuai latar belakang yang telah diuraikan di atas, maka dapat dirumuskan sebuah pokok permasalahan, diantaranya:

a. Bagaimana membuat suatu sistem yang dapat membantu pengendara sepeda motor saat terjadi perampasan sepeda motor saat berkendara.

b. Bagiamana membuat pandangan pengendara tetap baik ketika berkendara di saat hujan.

c. Bagaimana membuat sistem yang otomatis saling terkoneksi saat di dekatkan.

d. Bagaimana membuat fungi wiper otomatis dan kendali listrik bisa.dapat dijalankan bersamaan 


\section{Tujuan dan Manfaat}

a. Tujuan dari penelitian ini adalah

1) Menciptakan sebuah alat yang dapat mengatasi masalah yang terjadi pada pengendara sepeda motor ketika hujan.

2) Menciptakan sebuah alat yang dapat membantu pengendara saat terjadi perampasan paksa sepeda motor.

3) Menciptakan sebuah alat yang mudah digunakan

b. Mamfaat dari penelitian ini adalah

1) Pengendara sepeda motor dapat melaju dengan baik selama hujan dengan menggunakan helm

2) Jarak pandang yang tadinya terbatas kini menjadi lebih baik daripada sebelumnya.

3) Pengguna sepeda motor dapat mematikan sepeda motor miliknya dengan menekan tombol pada helm ketika terjadi hal-hal yang tidak diinginkan selama perjalanan sesembari mengulur waktu meminta pertolongan

\section{Tinjauan Pustaka}

Tinjauan pustaka dalam penelitian ini adalah sebagai berikut Adi Prasettio (2013) dalam judul "Sistem Kendali Wiper Pada Helm Dengan Sensor Berbasis Mikrokontroler Atmega 8535" pada Fakultas Ilmu Komputer, Universitas Gunadarma

Linus Nara Paradhana (2015) dalam pembuatan perangkat "Helm Anti Begal" jurusan IPA SMA N 16 Surabaya

\section{METODE PENELITIAN}

$\mathrm{Bab}$ ini berisi tentang pembahasan tentang hasil dan kerja alat secara menyeluruh terdiri dari analisa, perancangan, dan implementasi.

\section{A. Analisa}

Analisa yang dilakukan dalam pembuatan proyek ini adalah

a. Analisis sistem berjalan merupakan proses kerja yang terjai saat ini atau yang sedang berlangsung sebelum dikembangkan menjadi proyek. Dalam tahap analisis berjalan ini digambarkan dalam bentuk activity dan use case.

b. Analisis sistem usulan, berisi tentang kebutuhan system yang akan digunakan untuk membangun pintu air otomatis ini dalam bentuk gambar.

\section{B. Perancangan}

Pada tahap perancangan pembuatan wiper otomatis pada helm dan kendali kelistrikan pada motor berbasis mikrokontroler arduino ini dibagi menjadi tiga yaitu perancangan perangkat untuk fungsi wiper otomatis, perancangan perangkat untuk mematikan motor, dan perancangan perangkat untuk menghidupkan motor.

\section{Implementasi}

Implementasi ini menjelaskan semua proses instalasi dari mulai instalasi perangkat keras, instalasi perangkat lunak, tahap pemograman, serta dilakukan tahapan pengujian yang berguna untuk mengetahui bahwa perangkat yang di pasang dapat berfungsi benar atau tidak. Pada tahap pengujian ini dilakukan dengan metode blackbox guna mendapatkan hasil yang terbaik.

\section{PEMBAHASAN}

A. Analisis

1) Analisa Sistem Berjalan

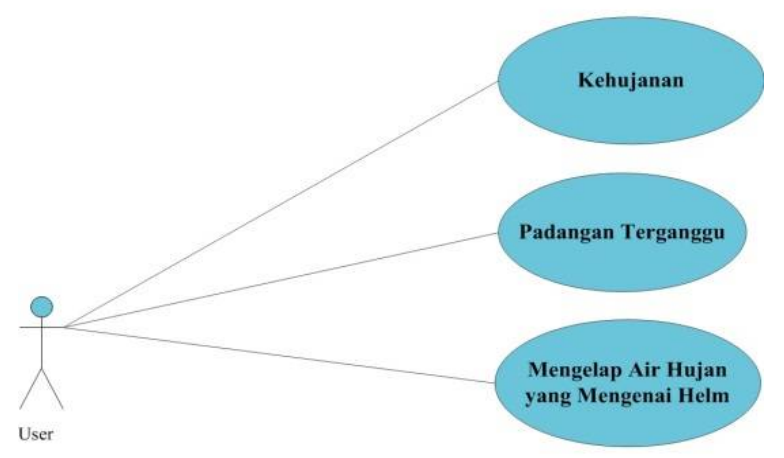

Gambar 1. Use Case pengendara kehujanan

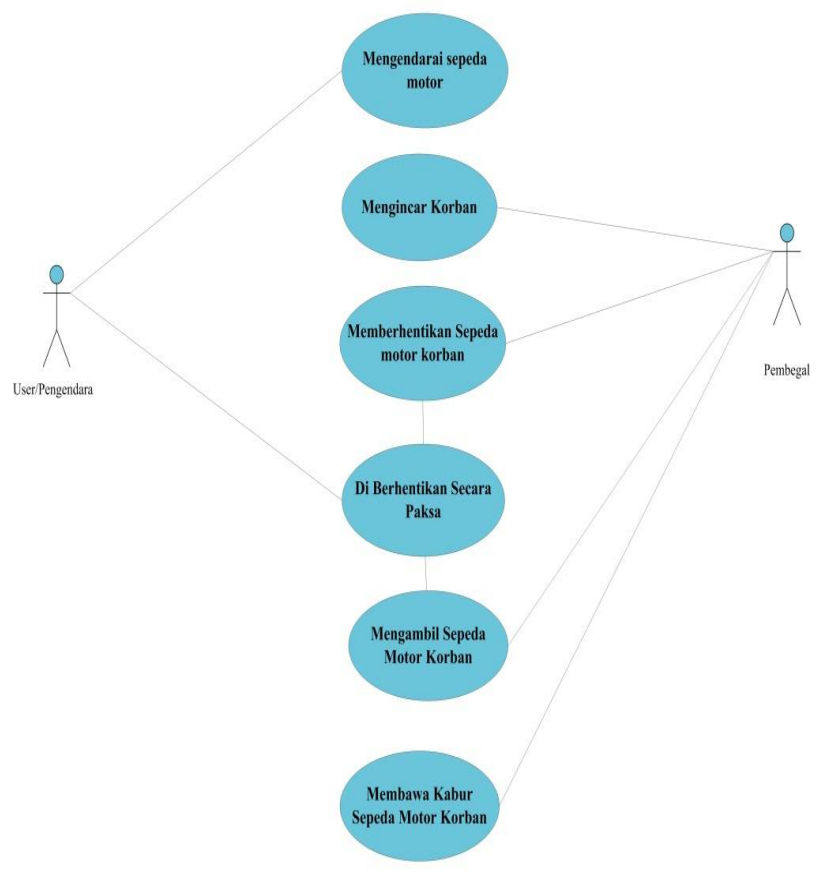

Gambar 2. Use Case pembegalan 


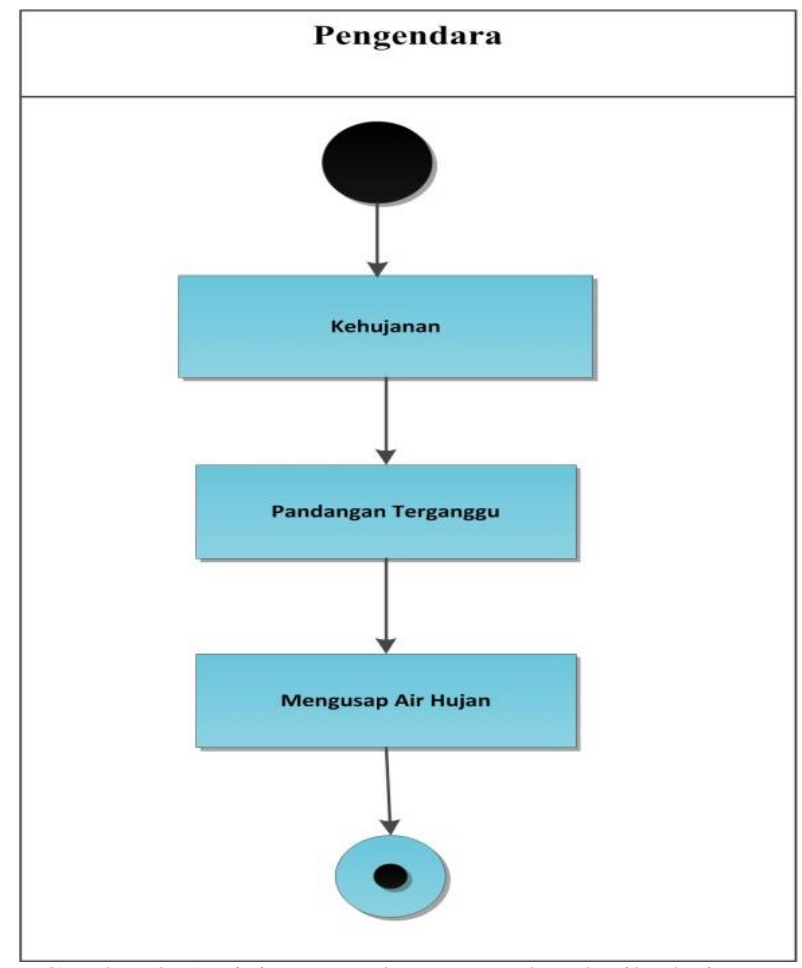

Gambar 3. Activity Prosedur pengendara ketika hujan

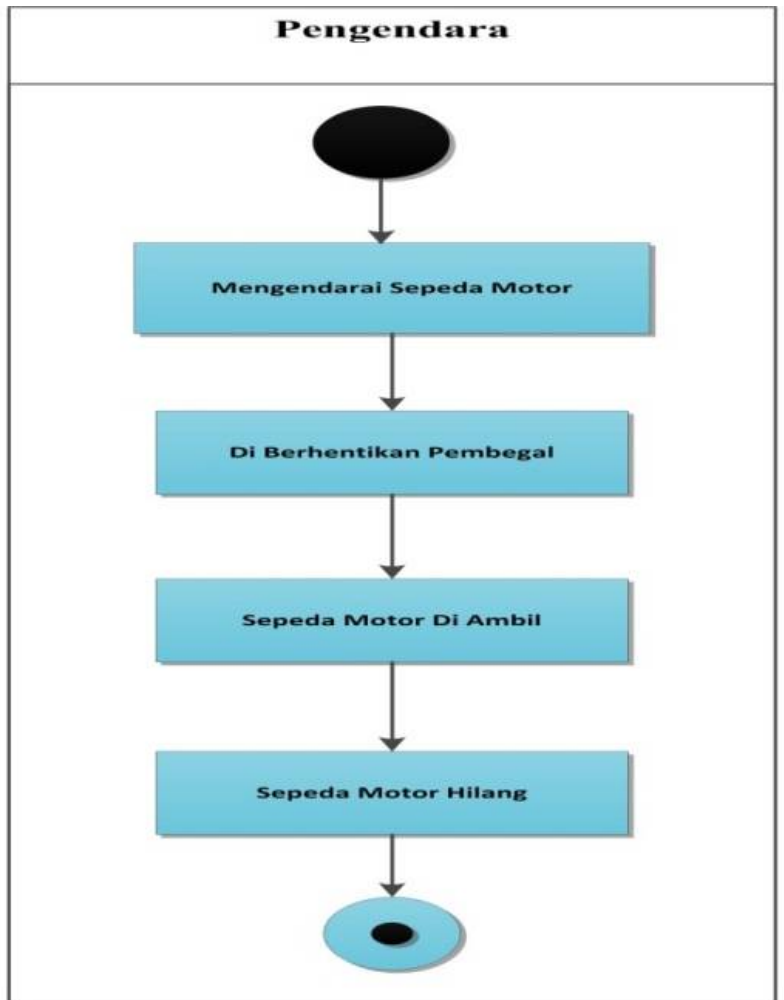

Gambar 4. Activity Prosedur pengendara

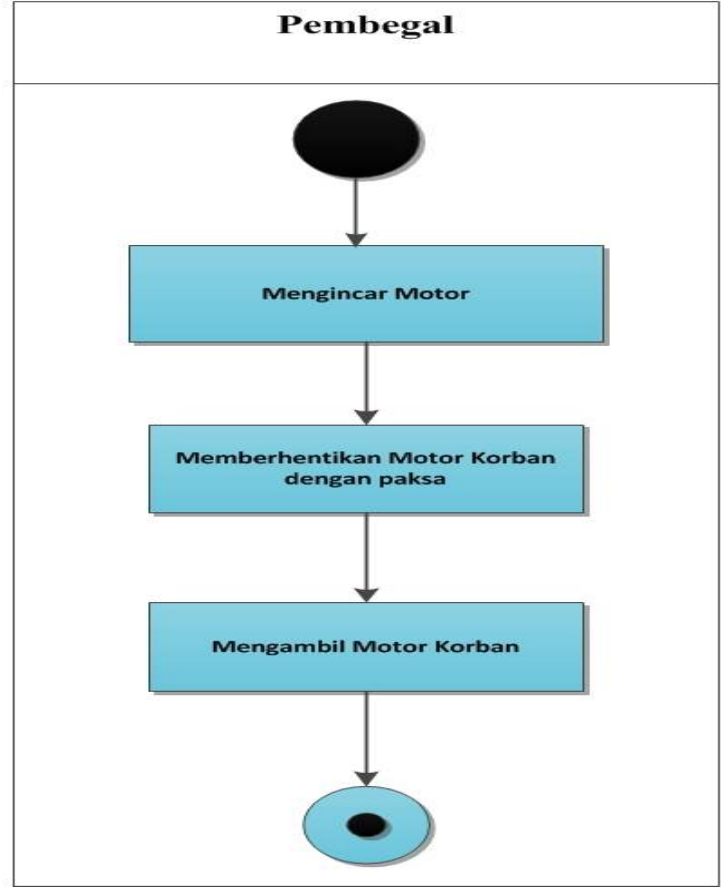

Gambar 5. Activity Prosedur pembegal

2) Analisis Sistem Usulan

Dalam analisis ini digunakan gambar untuk memudahkan penjelasan

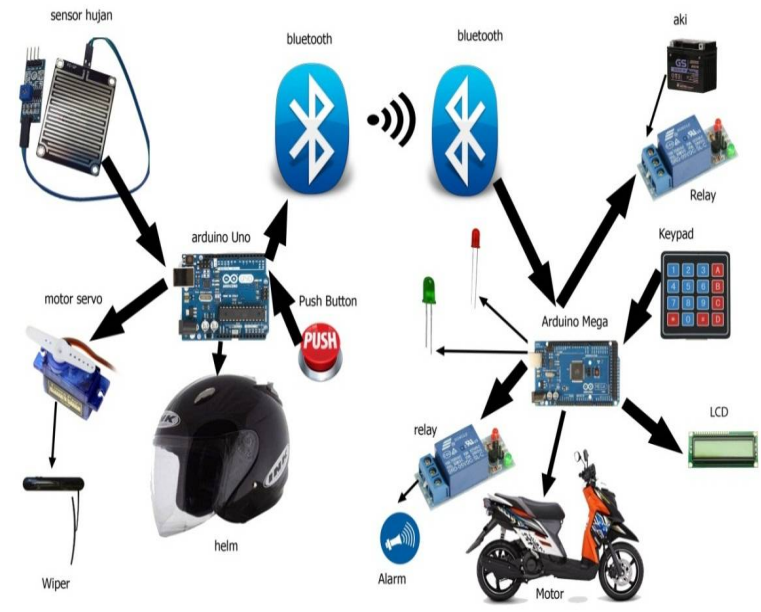

Gambar 6. Gambaran Sistem Usulan

Pada gambar menampilkan Analisa usulan yang akan di bahas. Pada helm terdapat Se $\mathrm{n}$ nsor hujan yang berfungsi sebagai perangkat yang menditeksi curah hujan yang kemudian akan di proses arduino Nano untuk menggerakkan servo yang sudah terpasang wiper. Push button berfungsi sebagai tombol yang antinya setelah di proses arduino Uno maka akan akan mengirim data lewat bluetooth. Pada motor terdapat perangkat Bluetooth yang berfungsi sebagai penerima data lewat 
sinyal nirkabel yang kemudian di proses oleh arduino Mega untuk mematikan sepeda motor melalui perangkat relay yang tersambung pada aki. Terdapat pula Keypad yang berfunsi sebagai tombol karakter beruapa angka dan huruf yang digunakan untuk mengisi password menghidupkan motor. LCD disini berfungsi sebagai monitor. Terdapat pula led sebagai indicator password benar dan salah.

\section{B. Perancangan}

Dalam merancang sistem pengunaan wiper otomatis pada helm dan kendali kelistrikan pada motor berbasis mikrokontroler Arduino ini terbagi menjadi beberapa bagian yaitu, perancangan perangkat keras (hardware) pada helm dan motor, perancangan perangkat lunak (Software).

Alat ini memiliki dua fungsi yang dapat dilakukan, yang pertama adalah fungsi sebagai pengusap / penyapu tetesan air hujan yang mengenai kaca pada helm dan yang kedua adalah berfungsi sebagai pengendali kelistrikan yang dimana bisa mematikan arus listrik pada motor yang dikendalikan melalui helm.

Pada fungsi yang pertama sebagai pengusap / penyapu tetesan air hujan alat ini di menggunakan mikrokontroler Arduino Nano sebagai pemproses yang terhubung dengan sensor hujan dan servo. Pada proses awal sensor hujan akan menditeksi curah air hujan dan merubahnya menjadi sinyal berupa nilai-nilai angka yang kemudian sensor akan mengirimkan sinyal tersebut ke mikrokontroler Arduino Nano yang selanjutnya pada tingkatan / nilai tertentu mikrokontroler akan memerintahkan servo yang telah di modifikasi dan di tambahkan wiper untuk berputar 180 derajat bolak balik dengan waktu tertentu.

Pada fungsi yang kedua sebagai pengendali listrik yang dimana pada helm terdapat tombol push button yang dapat mematikan sepeda motor dari jarak tertentu dengan cara memutuskan arus listrik yang berasal dari aki motor. Proses awalnya adalah user / pengguna menekan tombol push button tersebut dan selanjutnya mikrokontroler Arduino Uno pada helm akan mengirimkan kode biner kepada mikrokontroler Arduino Mega pada motor yang sudah tersambung otomatis melalui media Bluetooth dan selanjutnya Arduino Mega akan memutuskan arus listrik dari aki motor tersebut dengan menggunakan relay sebagai alat pemutus arus listriknya. Untuk menghidupkan kembali motor tersebut di butuhkan suatu proses yang harus di lakukan user / pengguna untuk menyambung arus listrik yang sudah terputus tadi. Proses nya adalah user / pengguna harus memasukan password dengan cara menekan sejumlah kode rahasia pada Keypad yang sudah tersabung pada mikrokontroler arduino dan selanjutnya mikrokontroler Arduino Mega akan menyambung arus listrik tadi melalui relay sebagai alat penyambung arus listriknya.

\section{a. Deployment Diagram}

Deployment diagram merupakan gambarkan prosesproses berbeda pada suatu sistem yang berjalan. Berikut ini adalah Deploymen $t$ Diagram alat
Penggunaan Wiper Otomatis Pada motor dan Kendali Kelistrikan Pada Motor berbasis Mikrokontroller Arduino

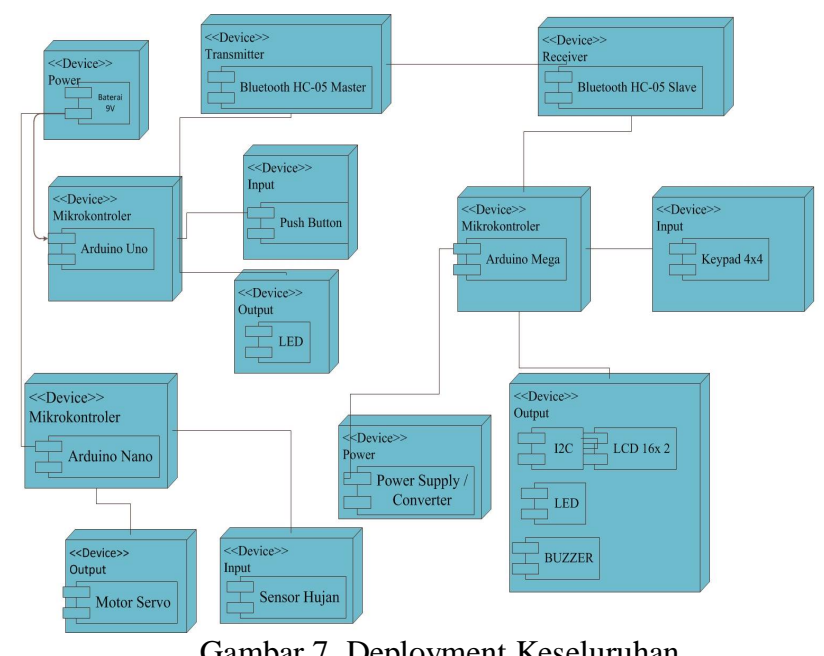

Gambar 7. Deployment Keseluruhan

Pada Deployment diagram tersebut di dapatkan informasi mengenai hardware yang digunakan. Pada Power terdapat Baterai 9v dan Power supply / Converter 9V Input terdapat push button, sensor hujan, Keypad. Pada output terdapat Motor Servo, LED, LCD dan sebagai media penghubung antar arduino terdapat Bluetooth yang berfungsi sebagai transmitter dan receiver.

b. Komponen Diagram

Perancangan perangkat keras ini bertujuan untuk memberikan gambaran umum tentang perangkat keras yang digunakan pada

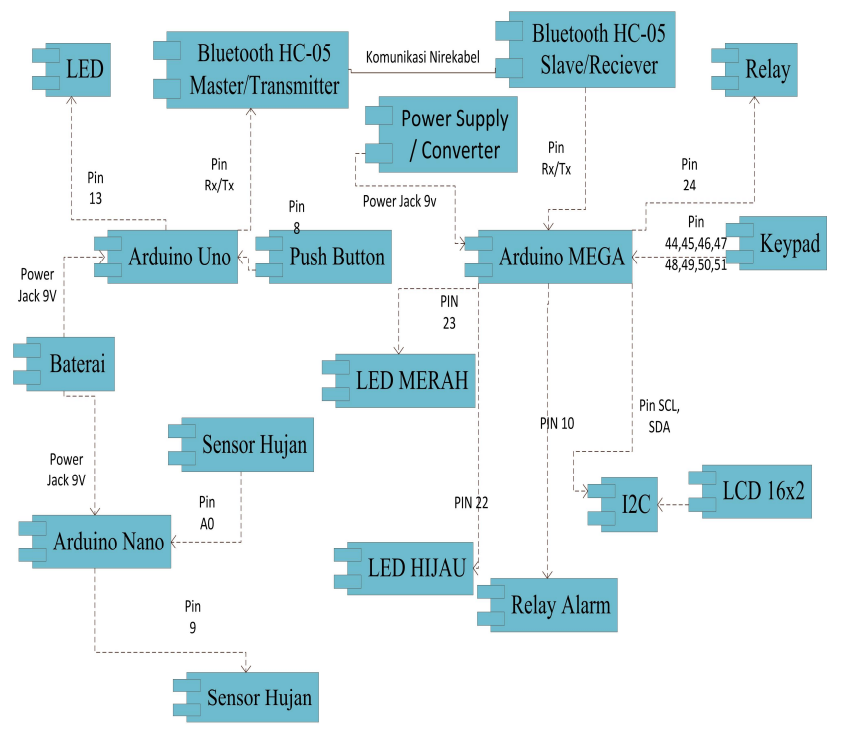

Gambar 8. Komponen Diagram Keseluruhan 
c. Perancangan

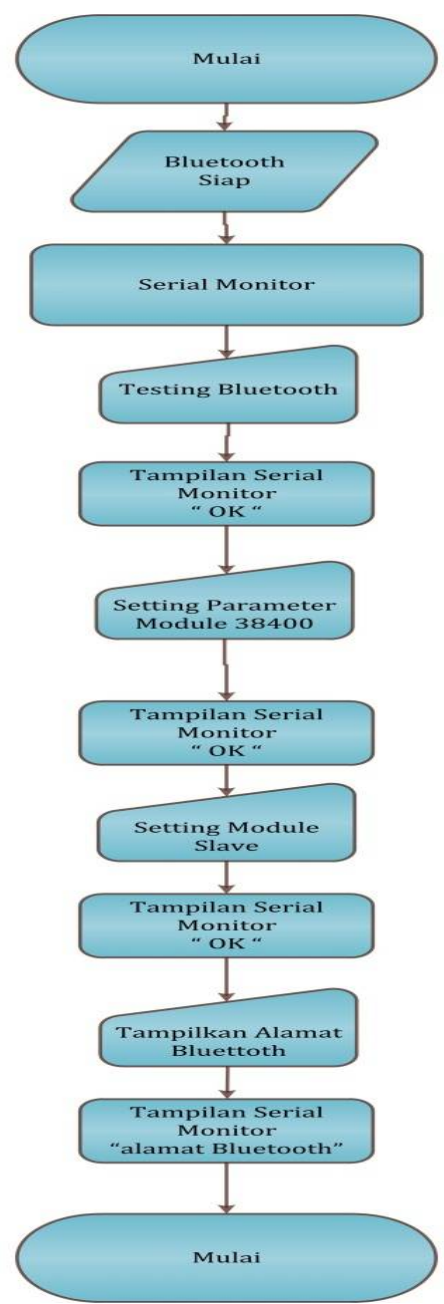

Gambar 9. flowchart Bluetooth Slave

\begin{tabular}{|ll|}
\hline 1. & Mulai \\
2. & Bluetooth Siap \\
3. Tampilkan Serial Monitor \\
4. Test Bluetooth \\
5. Tampilan serial monitor "OK" \\
6. Setting Paramter Bluetooth 38400; \\
7. Tampilan serial monitor "OK" \\
8. Setting Bluetooth menjadi Slave \\
9. Tampilan serial monitor "OK" \\
10. Tampilkan Alamat Bluetooth \\
11. Tampilan serial monitor "Alamat Bluetooth" \\
Selesai \\
\hline
\end{tabular}

d. Perancangan Bluetooth Master

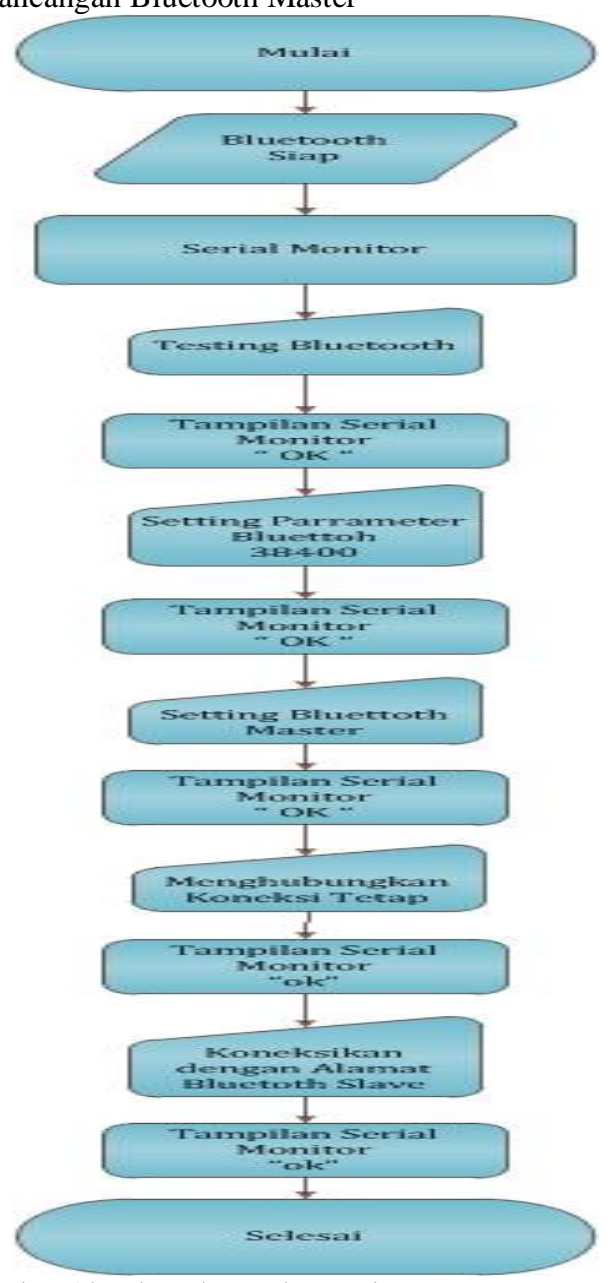

Gambar 10. Flowchart Bluetooth Master
1. Mulai
2. Bluetooth Siap
3. Tampilkan Serial Monitor
4. Test Bluetooth
5. Tampilan serial monitor "OK"
6. Setting Paramter Bluetooth 38400;
7. Tampilan serial monitor "OK"
8. Setting Bluetooth menjadi Master
9. Tampilan serial monitor "OK"
10. Menghubungkan koneksi tetap
11. Tampilan serial monitor "OK"
12. Koneksikan alamat Bluetooth Slave
13. Tampilan serial monitor "Alamat Bluetooth" Selesai 
e.Perancangan perangkat lunak wiper helm

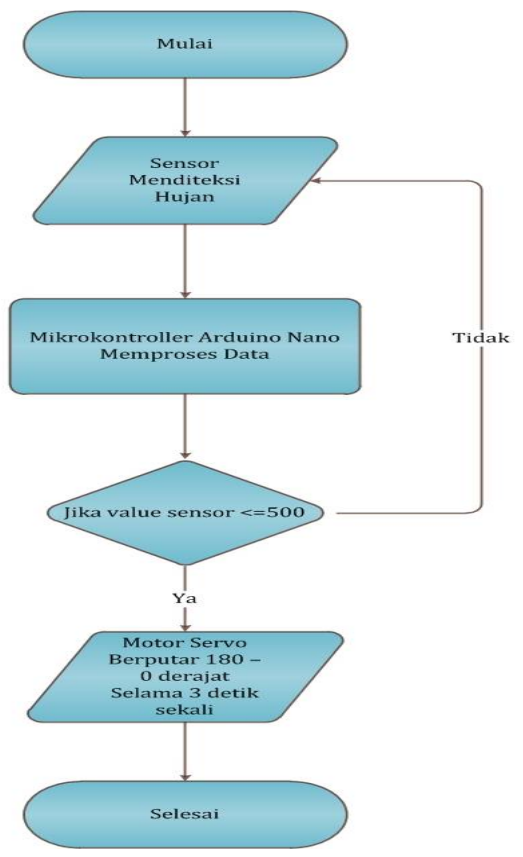

Gambar 11. Flowchart Perancangan Perangkat Lunak Wiper Helm

1. Mulai

2. Sensor Menditeksi Hujan;

3. Arduino Nano Memproses data

4. if (Value sensor kurang sama dengan dari 600) \{

5. Motor servo berputar 180 derajat - 0 derajat bolak balik selama 3 detik sekali.

6. Else

7. \{

8. Motor servo berada pada 0 derajat

9. $\}$

10. Selesai

f. Perancangan Lunak Untuk Mematikan Sepeda Motor

\begin{tabular}{|ll|}
\hline 1. & Mulai \\
2. Tombol Push button \\
3. If (puh button di tekan) \{ \\
4. Arduino Uno Memproses data; \\
5. Mengirim data lewat blueetoth transmitter; \\
6. Bluetooth Reciever menerima data dan \\
7. Mengirim data; \\
8. Arduino Mega menerima data; \\
9. \\
10. \\
11. Setor Mati; \\
\hline
\end{tabular}

g. Perancangan perangkat lunak untuk menghidupkan sepeda motor

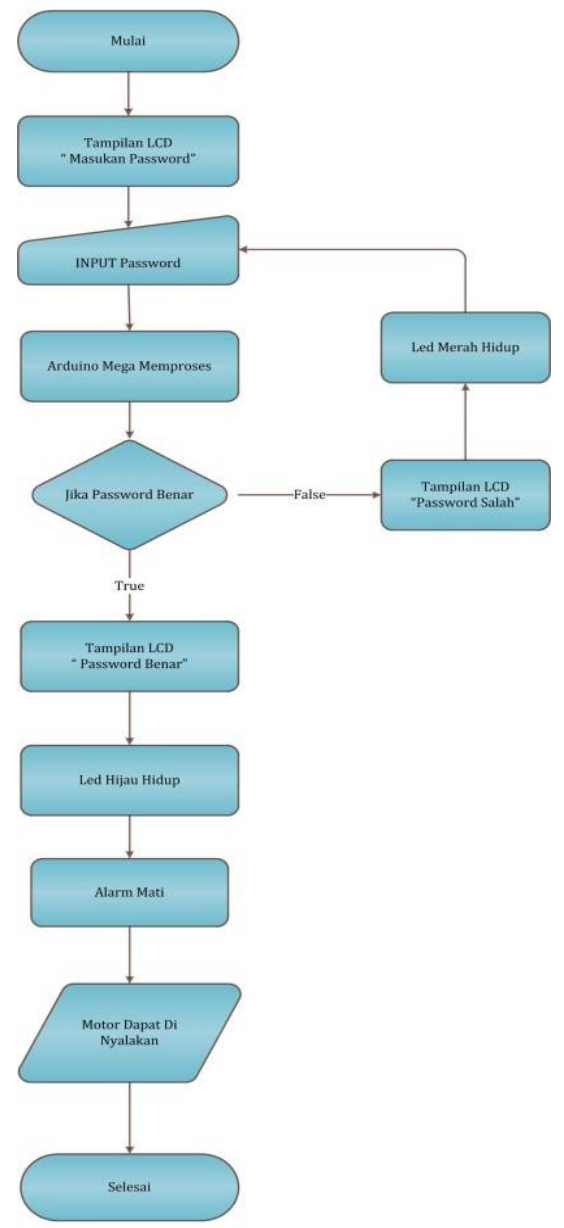

Gambar 12. Flowchart Perancangan Perangkat Lunak Untuk Menghidupkan Sepeda Motor

1. Mulai
2. Tampilan LCD
3. Input/masukan Password
4. Arduino Memproses data
5. If (password benar) \{
6. LCD menampilkan Pesan "Password
$\quad$ Benar";
7. Lampu Led hidup menyala ;
8. Alarm Mati
9. Motor siap digunakan
10. Else \{
11. Lcd menampilakan Pesan "Password
$\quad$ Salah"
12. Led merah menyala;
13. Masukan ulang password
14. Selesai;




\section{Pengujian}

Pengujian dilakukan dengan metode Blackbox dan selama 7 hari. Adapun daftar pengujian yang dilakukan adalah sebagai berikut.

a. Pengujian Sensor Hujan

Tabel 1. Pengujian Sensor Hujan

\begin{tabular}{|l|l|l|l|}
\hline No & Skenario & $\begin{array}{l}\text { Hasil yang Di } \\
\text { harapkan }\end{array}$ & $\begin{array}{l}\text { Kesim } \\
\text { pulan }\end{array}$ \\
\hline 1 & $\begin{array}{l}\text { Memberikan Air } \\
\text { Pada Flat } \\
\text { Sensor Hujan }\end{array}$ & $\begin{array}{l}\text { Serial Monitor } \\
\text { Menampilkan } \\
\text { Value }\end{array}$ & Valid \\
\hline
\end{tabular}

b. Pengujian Rangkaian Wiper Helm

Tabel 2. Pengujian Rangkaian Wiper Helm

\begin{tabular}{|l|l|l|l|}
\hline No & Skenario & $\begin{array}{l}\text { Hasil yang Di } \\
\text { harapkan }\end{array}$ & $\begin{array}{l}\text { Kesim } \\
\text { pulan }\end{array}$ \\
\hline 1. & $\begin{array}{l}\text { Memberikan Air } \\
\text { Pada Flat Sensor } \\
\text { Hujan }\end{array}$ & $\begin{array}{l}\text { Motor Servo } \\
\text { Berputar 180 - 0 } \\
\text { Selama 3 detik } \\
\text { sekali }\end{array}$ & \\
\hline & & & \\
\hline
\end{tabular}

c. Pengujian Rangkaian Kendali kelistrikan (Motor mati) pada motor

Tabel 3. Pengujian Rangkaian Kendali Kelistrikan (Motor Mati) pada Motor

\begin{tabular}{|c|c|c|c|}
\hline No & $\begin{array}{l}\text { Skena } \\
\text { rio }\end{array}$ & Hasil yang Di harapkan & $\begin{array}{l}\text { Kesim } \\
\text { pulan }\end{array}$ \\
\hline \multirow[t]{2}{*}{1} & $\begin{array}{l}\text { Teka } \\
\mathrm{n} \\
\text { Tomb } \\
\text { ol }\end{array}$ & $\begin{array}{l}1 . \\
\text { Relay Keadaan Mati } \\
\text { (Keadaan Motor Mati) }\end{array}$ & \multirow[t]{2}{*}{ Valid } \\
\hline & $\begin{array}{l}\text { Push } \\
\text { butto } \\
n\end{array}$ & $\begin{array}{ll}\text { 2. } & \text { Relay Alarm Hidup } \\
\text { (Klakson Berbunyi) }\end{array}$ & \\
\hline
\end{tabular}

d. Pengujian Rangkaian Kendali kelistrikan (Motor dapat / siap di gunakan) pada motor.

Tabel 4. Pengujian Rangkaian Kendali kelistrikan (Motor dapat / siap di gunakan) pada motor

\begin{tabular}{|l|l|l|l|}
\hline No & Skenario & $\begin{array}{l}\text { Hasil yang Di } \\
\text { harapkan }\end{array}$ & $\begin{array}{l}\text { Kesimp } \\
\text { ulan }\end{array}$ \\
\hline 1 & $\begin{array}{l}\text { Menekan } \\
\text { Tombol } \\
\text { Keypad }\end{array}$ & $\begin{array}{l}\text { lcd Menampilkan } \\
\text { Pesan Dari Keypad }\end{array}$ & Valid \\
\hline 2 & $\begin{array}{l}\text { Memasukan } \\
\text { Kode } \\
\text { Password } \\
\text { dengan } \\
\text { Benar }\end{array}$ & $\begin{array}{l}\text { 1. lcd menampilkan } \\
\text { pesan "Password }\end{array}$ & Valid \\
& $\begin{array}{l}\text { Benar" Relay Keadaan } \\
\text { Hidup (Motor Siap }\end{array}$ & \\
\hline
\end{tabular}

\begin{tabular}{|c|c|c|c|}
\hline & & digunakan) & \\
\hline & & $\begin{array}{l}\text { 3. Led Hijau } \\
\text { Menyala }\end{array}$ & \\
\hline \multirow[t]{2}{*}{3} & \multirow[t]{2}{*}{$\begin{array}{l}\text { Masukan } \\
\text { Password } \\
\text { Dengan } \\
\text { Salah }\end{array}$} & $\begin{array}{l}\text { 1. lcd menampilkan } \\
\text { pesan "Password } \\
\text { Benar" }\end{array}$ & \multirow[t]{2}{*}{ Valid } \\
\hline & & $\begin{array}{l}\text { 2. Relay Keadaan } \\
\text { Hidup (Motor Siap } \\
\text { digunakan) }\end{array}$ & \\
\hline
\end{tabular}

e. Pengujian Menggunakan Sensor Hujan dan Push button Secara Bersama-samaan

Tabel 5. Pengujian Menggunakan Sensor Hujan dan Push button Secara Bersama-samaan

\begin{tabular}{|l|l|l|l|}
\hline No & Skenario & $\begin{array}{l}\text { Hasil Yang } \\
\text { Diharapkan }\end{array}$ & Kesimpulan \\
\hline 1 & Menekan & Relay & Valid \\
& Tombol Push & Keadaan & \\
& button dan & Mati & \\
& Memberi air & (Keadaan & \\
& pada sensor & Motor Mati) & \\
& hujan & dan Motor & \\
& & servo & \\
& & & \\
\hline
\end{tabular}

f. Pengujian koneksi Bluetooth

Tabel 6. Pengujian koneksi Bluetooth

\begin{tabular}{|c|c|c|}
\hline No & Jarak & Status \\
\hline 1 & 1 Meter & Terkoneksi \\
\hline 2 & 2 Meter & Terkoneksi \\
\hline 3 & 3 Meter & Terkoneksi \\
\hline 4 & 4 Meter & Terkoneksi \\
\hline 5 & 5 Meter & Terkoneksi \\
\hline 6 & 6 Meter & Terkoneksi \\
\hline 7 & 7 Meter & Terkoneksi \\
\hline 8 & 8 Meter & Terkoneksi \\
\hline 9 & 9 Meter & Terkoneksi \\
\hline 10 & 10 Meter & Terkoneksi \\
\hline 11 & 11 Meter & Terkoneksi \\
\hline 12 & 12 Meter & Terkoneksi \\
\hline 13 & 13 Meter & Tidak \\
& & Terkoneksi \\
\hline
\end{tabular}

\section{PENUTUP}

A. Kesimpulan

Setelah melakukan perancangan, implementasi dan penelitian terdapat beberapa kesimpulan yang dapat dikemukakan antara lain adalah 
- Prototype alat ini dapat berkerja dengan baik saat terjadi perampasan sepeda motor dengan cara menekan tombol push button.

- Ptototype alat ini dapat membantu pengendara sepeda motor yang mengalami masalah pandangan yang terganggu saat terjadi hujan karena alat ini dilengkapi servo yang dapat menggerakan wiper untuk mengusap kaca helm dari air yang mengenai helm.

- Peralatan mudah digunakan karena untuk fungsi pengusapan kaca helm dilakukan secara otomatis dengan menggunakan sensor hujan, dan untuk fungsi mematikan kendaraan bermotor juga mudah digunakan karena cukup menekan tombol yang terdapat pada helm.

- Prototype alat ini dapat terkoneksi otomatis antar Bluetooth.

\section{B. Saran}

Berdasarkan perancangan dan kesimpulan di atas ada beberapa yang harus saran yang dapat diberikan dalam rangka pengembangan prototype Penggunaan Wiper Otomatis pada Helm dan Kendali Listrik pada Motor Berbasis Mikrokontroler Arduino.

- Untuk pengembangan kedepannya prototype ini terdapat pengunci roda / pengereman sepeda motor yang dapat di kendalikan dengan helm, menggunakan RFID sebagai pengganti kunci motor yang terdapat banyak kelemahan, menambahkan gps tracker, dll.

- Desain alat diharapkan lebih stylis agar menambah minat masyarakat dalam menggunakan alat ini.

- Dapat diproduksi masal dengan harga yang terjangkau.

- Di lengkapi dengan solar cell yang digunakan untuk memberi daya tambahan.

- Agar lebih sempurna Wiper helm harus di rancang khusus.

\section{DAFTAR PUSTAKA}

[1] Andrianto, Heri., Aan Darmawan. 2016. Arduino Belajar Cepat dan Pemograman. Bandung: Informatika

[2] Aritonang, Boas, Drs. 2005. Peralatan Kontrol pada Sistem Tenaga Listrik dan Pnuematik. Medan : PPPG Teknologi Medan

[3] Badan Pusat Statistika, Jumlah kendaraan Sepeda Motor, http://bps.go.id/linkTabelStatis/view/id/1413. Di akses 10 mei 2016.

[4] Hartono, Jogiyanto. 2005. Analisis dan Desain Sistem Informasi, Edisi III. Yogyakarta: ANDI

[5] Munawar, 2005. Pemodelan Visual dengan UML. Graha Ilmu, Yogyakarta
[6] Pressman, Roger S. (2007). Rekayasa Perangkat Lunak: pendekatan praktisi (Buku1). Beizer, B. (1995).BlackBox Testing, Wiley. Yogyakarta: Andi

[7] Syahwil, Muhammad., 2013. Panduan Mudah Simulasi \& Praktek Mikrokontroler Arduino. Yogyakarta: Penerbit Andi.

[9] Thomas H. Cormen, Charles E. Leiseson and Ronald L. Rivest. 1994. Algorithms. McGraw-Hill Book Company. North America.

[10]Usman, Nurdin. 2002 .Konteks Implementasi Berbasis Kurikulum. Jakarta:PT. Raja Grafindo Persada. 